\title{
RENAL FUNCTION AFTER CORONARY BYPASS SURGERY IN PATIENTS WITH PRE-DIABETES
}

\author{
Kremneva L. V., Suplotov S. N.
}

Aim. To reveal the predictors of renal dysfunction due to surgical revascularization of myocardium in stable angina patients with prediabetes.

Material and methods. Totally, 48 patients with prediabetes studied, having indications for coronary bypass grafting (CBG) at the age $60 \pm 7,4$ years with coronary heart disease (CHD) anamnesis $6 \pm 5,4$ years. Multivessel disease of coronary vessels had $68,8 \%$ of patients, LCA stem stenosis $>50 \%$ had $10,9 \%$ of patients. On-pump CBG was done in $87,5 \%$ of patients, off-pump $-12,5 \%$. Duration of on-pump period was $95 \pm 23 \mathrm{~min}$., number of distal anastomoses for one patient $-2,8 \pm 0,8$. Baseline, on the first and second days post-CBG, and if needed later, the creatinin concentration was measured in the blood, as glomerular filtration rate (GFR) by CKD-EPI equation. Of the development of renal dysfunction in CBG we decided if GFR decreased below $60 \mathrm{~mL} / \mathrm{min} / 1,73 \mathrm{~m}^{2}$. In statistics we took continuous variables as $\mathrm{M} \pm \mathrm{SD}$ and as $\mathrm{Me}(25 \%-75 \%)$ depending on the type of distribution. Renal dysfunction predictors were defined with the method of staged regression.

Results. In patients with stable angina and prediabetes we found moderate transient decrease of GFR after CBG comparing to the baseline level with Me 89,4 $(78-105)$ to $\mathrm{Me} 77,8(59-96) \mathrm{mL} / \mathrm{min} / 1,73 \mathrm{~m}^{2}$ ( $\left.p<0,01\right)$. Significant decrease of GFR after CBG had the patients with in-hospital complications (introperational myocardial infarction, acute heart failure, atrial fibrillation paroxysm) - Me 92 (82-107) and Me $72,4(56-89) \mathrm{mL} / \mathrm{min} / 1,73 \mathrm{~m}^{2}, \mathrm{p}=0,000$ differ from the patients groups not having complications, $p=0,797$. The part of persons developing $C B G$ related renal dysfunction was $21,7 \%$. Decrease of GFR $<60 \mathrm{~mL} / \mathrm{min} / 1,73 \mathrm{~m}^{2}$ after CBG is associated with older age, lower baseline GFR and longer on-pump period.

Conclusion. Among patients with stable angina and pre-diabetes the part of those developing CBG related renal dysfunction was $21,7 \%$. The increase of on-pump time more than Me 105 (86-136) minutes significantly increased the relative risk of renal dysfunction development after CBG.

Russ J Cardiol 2016, 4 (132), Engl.: 175-178

http://dx.doi.org/10.15829/1560-4071-2016-4-eng-175-178

Key words: prediabetes, renal dysfunction, coronary bypass graft.

State Educational Institution of Higher Professional education, Tyumen State Medical University' of the Ministry of Health of the Russian Federation, Tyumen, Russia

Corresponding author. Kremneva L.V. Professor of the Clinical Laboratory Diagnostics Department, Advanced Training Faculty and Reskilling Faculty. 625037, Tyumen, Belinskogo Str., 3, app. 109. E-mail: KremnevaLV01@gmail.com

$\mathrm{CHD}$ - coronary heart disease, $\mathrm{CP}$ - cardiopulmonary bypass, $\mathrm{MI}$ - myocardial infarction, CABG - coronary artery bypass grafting, CMD - carbohydrate metabolism disorders, DM - diabetes mellitus, GFR - glomerular filtration rate, GTT - glucose tolerance test, FC - functional class, CKD - chronic kidney disease, CHF - chronic heart failure, ECG - electrocardiography, EchoCG echocardiography, $\mathrm{TnT}$ - troponin T.

Received 15.04.2016.

Revision received 18.04.2016

Accepted 25.04.2016.

\section{ФУНКЦИЯ ПОЧЕК ПОСЛЕ КОРОНАРНОГО ШУНТИРОВАНИЯ У ПАЦИЕНТОВ С ПРЕДИАБЕТОМ}

Kremneva L. V., Suplotov S. N.

Цель. Выявить предикторы развития дисфункции почек после хирургической реваскуляризации миокарда у больных стабильной стенокардией с предиабетом. Материал и методы. Обследовано 48 больных с предиабетом, имеющих показания к коронарному шунтирования (КШ) в возрасте $60 \pm 7,4$ лет с длительностью ишемической болезни сердца $6 \pm 5,4$ года. Многососудистое поражение коронарных сосудов имелось у 68,8 \%, стеноз ствола левой коронарной артерии $>50 \%$ - у 10,9\% лиц. Операция КШ в условиях искусственного кровообращения (ИК) выполнена у 87,5 \%, на работающем сердце - у 12,5\% больных. Длительность ИК составила 95 23 мин., количество дистальных анастомозов на одного пациента $-2,8 \pm 0,8$. Исходно, в первые и вторые сутки после КШ, при необходимости в более поздние сроки, измеряли концентрацию креатинина в крови, рассчитывали скорость клубочковой фильтрации (СКФ) по формуле CKD-EPI. O развитии дисфункции почек в связи с КШ судили по снижению СКФ ниже 60 мл/мин/1,73 м². При статистической обработке материалов непрерывные переменные представлены как M \pm SD или как Me (25 \%-75 \%) в зависимости от типа распределения. Предикторы развития почечной дисфункции определяли методом пошагового регрессионного анализа.

Результаты. У больных стабильной стенокардией с предиабетом выявлено умеренное транзиторное снижение СКФ после КШ в сравнении с исходным уровнем с Ме 89,4 (78-105) до Ме 77,8 (59-96) мл/мин/1,73 м² (р<0,01). Значи-

Coronary artery bypass grafting (CABG) is one of the most effective treatments for coronary artery disease (CHD) patients with multivessel coronary artery disease. However, $\mathrm{CABG}$, as any invasive procedure, has a certain risk of complications, among which renal dysfunction is quite frequent. According to different authors, the incidence of renal dysfunction after CABG is between 8 and мое снижение СКФ после КШ имелось у лиц с госпитальными осложнениями (интраоперационный инфаркт миокарда, острая сердечная недостаточность, пароксизм фибрилляции предсердий) - Ме 92 (82-107) и Ме 72,4 (56-89) мл/ мин $/ 1,73$ м $^{2}, p=0,000$ в отличие от группы пациентов, не имевших осложнений, $\mathrm{p}=0,797$. Доля лиц с развившейся в связи с КШ почечной дисфункцией составила 21,7\%. Снижение СКФ <60 мл/мин/1,73 м² после КШ ассоциировано с более старшим возрастом, более низкой исходной СКФ и более продолжительным периодом ИК.

Заключение. Среди больных стабильной стенокардией с предиабетом доля лиц с развившейся в связи с КШ почечной дисфункцией составила 21,7\% Увеличение продолжительности ИК более Ме 105 (86-136) минут значимо повышало относительный риск развития дисфункции почек после КШ.

Российский кардиологический журнал 2016, 4 (132), Англ.: 175-178 http://dx.doi.org/10.15829/1560-4071-2016-4-eng-175-178

Ключевые слова: предиабет, почечная дисфункция, коронарное шунтирование.

State Educational Institution of Higher Professional education, Tyumen State Medical University' of the Ministry of Health of the Russian Federation, Тюмень, Россия.

$30 \%$ and is associated with an increased risk of hospital complications and mortality [1-3].

Factors, predisposing for the renal dysfunction process after CABG, include age, diabetes mellitus (DM), chronic heart failure (CHF), increased baseline blood creatinine level, a long period of cardiopulmonary bypass $(\mathrm{CP})$, aorta occlusion, etc. [2, 4]. 
Among patients undergoing surgical myocardial revascularization, about $30-40 \%$ are people with carbohydrate metabolism disorders (CMD) [5]. However, the incidence and risk factors for renal dysfunction after CABG among these patients are not studied.

The aim of the study was to identify predictors of renal dysfunction in connection with surgical myocardial revascularization in patients with stable angina with early carbohydrate metabolism disorders.

\section{Materials and methods}

The study included patients with chronic CHD with early CMD admitted to the hospital for CABG surgery. Indications for $\mathrm{CABG}$ were determined in accordance with the recommendations on myocardial revascularization (ESC/EACTS, 2010) [6]. Exclusion criteria from the study included age over 75 years, DM, myocardial infarction (MI) and cerebral crisis not older than two months, significant stenoses of the brachiocephalic arteries, valvular heart disease and left ventricular aneurysm, which required surgical treatment, erosive gastritis and exacerbation of peptic ulcer, acute inflammatory diseases and exacerbation of chronic inflammatory diseases, severe diseases of kidneys, liver and lungs, terminal CHF, cancer pathology.

Before surgical myocardial revascularization, all patients underwent an examination including blood tests, urine tests, biochemical blood test, in particular creatinine level measurement, an oral glucose tolerance test (GTT), electrocardiography (ECG), echocardiography (EchoCG), ultrasound examination of brachiocephalic arteries, arteries and veins of the lower extremities, fibrogastroscopy, coronary angiography by M. R. Judkins technique (1967) using a Philips Polidiagnost C (Netherlands) angiographic complex.

Blood creatinine was measured by Jaffe method using Synchron CX Systems (Beckman Coulter, USA). Kidney function was assessed by glomerular filtration rate (GFR) in accordance with the classification of chronic kidney disease (CKD) NKF/ KDOQI (2002) [7]. GFR was calculated by the CKD-EPI formula [8]. All patients, except patients with known DM, underwent an oral GTT using standard methods. The criteria for diagnosis of early CMD (pre-diabetes), which included fasting hyperglycemia (study twofold of fasting glucose $>5,5<6,1 \mathrm{mmol} / \mathrm{l}$ ) and impaired glucose tolerance test (IGTT) (blood glucose 2 hours after a glucose load $\geq 7,8<11,1 \mathrm{mmol} / \mathrm{l}$ ), were conventional (WHO, 1999; WHO and ADA, 2003) [9]. Blood glucose was measured by an electrochemical method with chip sensors using BIOSEN C_line clinic equipment (Germany). On days 1 and 2 after $\mathrm{CAB} G$ or later, if necessary, blood creatinine was re-measured and GFR was calculated by the above mentioned formula. The renal dysfunction process due to CABG was judged by the decrease in GFR less than $60 \mathrm{~mL} / \mathrm{min} / 1,73 \mathrm{~m}^{2}$. One day after CABG, and later as necessary, blood troponin T level ( $\mathrm{TnT}$ ) was measured in all patients using the Cardiac reader semiquantitative immune chromatographic assay device (Roche Diagnostics, Switzerland).

The following hospital complications were evaluated before discharge: cases of intraoperative MI, acute heart failure, which required the use of inotropic agents; paroxysmal atrial fibrillation, cardiac death. Intraoperative MI was diagnosed based on the recommendations (2007).

The ethics committee approved the study protocol. All participants provided written informed consent prior to inclusion.

Among 200 patients with chronic CHD admitted to hospital for CABG, early CMD was detected in 64 (32\%) individuals. 10 patients were not included in further analysis by exclusion criteria. GFR was determined at least three times after CABG in 48 of 54 patients with early CMD. The average age of 48 patients with $\mathrm{CHD}$ with pre-diabetes was $60 \pm 7,4$ years; CHD duration was 6,2 $\pm 5,4$ years. There were $37(77,1 \%)$ men and 11 women $(22,9 \%)$. With reference to the classification by the Canadian Cardiovascular Society, FC II angina was diagnosed in $6(12,5 \%)$, FC III in $37(77,1 \%)$ and FC IV in 5 $(10,4 \%)$ patients. $39(81,3 \%)$ patients had a history of MI. According to the NYHA classification, symptoms of CHF I FC were found in $1(2,1 \%)$, II FC in $19(39,6 \%)$, and III FC in $28(58,3 \%)$ patients. $15(31,3 \%)$ patients smoked; 46 $(95,8 \%)$ patients had arterial hypertension, $27(56,3 \%)$ patients had obesity. GFR of under $60 \mathrm{~mL} / \mathrm{min} / 1,73 \mathrm{~m}^{2}$ before CABG was found in $1(2,1 \%)$ patient. Coronary angiography suggested single-vessel coronary disease in $5(10,4 \%)$ patients, two-vessel coronary disease in $10(20,8 \%)$ patients, multivessel coronary disease in $35(68,8 \%)$ patients, left main coronary artery stenosis greater than $50 \%$ in $5(10,9 \%)$ patients. Prior to CABG surgery, $23(47,9 \%)$ patients received angiotensin converting enzyme inhibitors or angiotensin II receptor blockers, $13(27,1 \%)$ patients received calcium antagonists, $46(95,8 \%)$ patients received beta-blockers, $24(50 \%)$ patients received statins, and $42(87,5 \%)$ patients received long-acting nitrates.

CABG under CP conditions was performed in $42(87,5 \%)$ patients and on a beating heart in $6(12,5 \%)$ patients. The duration of CP was $94,8 \pm 23$ minutes and of aorta occlusion $45,5 \pm 15$ minutes. The number of distal anastomoses per patient was $2,8 \pm 0,8$.

During the period of hospitalization $7(14,6 \%)$ cases of intraoperative MI, $13(27,1 \%)$ cases of acute heart failure, which required the use of inotropic agents, were registered; 10 $(20,8 \%)$ patients had paroxysmal atrial fibrillation. There were no deaths. TnT level in the whole sample of patients was $0,4 \pm 0,52 \mathrm{ng} / \mathrm{mL}$ and $1,3 \pm 0,74 \mathrm{ng} / \mathrm{mL}$ in patients with $\mathrm{MI}$. Complications during the hospital period (cases of intraoperative MI, acute heart failure, paroxysmal atrial fibrillation) occurred in $23(47,9 \%)$ patients; none of these complications was recorded in $25(52,5 \%)$ patients.

Statistical processing of the study materials was performed using the SPSS software package. Results are presented as $\mathrm{M} \pm \mathrm{SD}$, where $\mathrm{M}$ is an arithmetic mean and SD is a standard deviation, or as Me $(25 \%-75 \%)$, which is a median (interquartile range of percentile 25-percentile 75), depending on the distribution type. To assess the significance of differences between groups Student's t-test, Mann-Whitney U-test and the method of percent comparing were used. The reliability of the dynamics of indicators was determined using the paired Student's t-test or Wilcoxon test, depending on the distribution 
type. To identify characteristics of prognostic value, the stepwise logistic regression analysis method was used. Characteristics differences with a significance level of $\mathrm{P}<0,05$ were judged to be significant.

\section{Results}

In our study, we obtained data that the rate of early CMD in patients with $\mathrm{CHD}$, who were hospitalized for $\mathrm{CABG}$, was $32 \%$.

In patients with chronic $\mathrm{CHD}$ with early $\mathrm{CMD}$ a decrease in GFR after surgical myocardial revascularization compared with the baseline Me from 89,4 (77,6-104,8) to Me 77,8 $(58,7-$ $95,6) \mathrm{mL} / \mathrm{min} / 1,73 \mathrm{~m}^{2}(\mathrm{P}<0,010)$ was registered. The number of patients, who had GFR $<60 \mathrm{~mL} / \mathrm{min} / 1,73 \mathrm{~m}^{2}$ after $\mathrm{CABG}$, increased from $2,1 \%$ (1 patient) to $22,9 \%$ (11 patients) $(\mathrm{P}<0,064)$. The proportion of people with renal dysfunction due to CABG was $21,7 \%$ (10 patients). None of the patients had a reduction in GFR less than $30 \mathrm{~mL} / \mathrm{min} / 1,73 \mathrm{~m}^{2}$ after the intervention. The maximum decrease in GFR occurred on the day one or two after CABG and was transient; by the time of hospital discharge, GFR reached baseline in most patients.

Dynamics of GFR in patients with renal dysfunction due to CABG was the following: Me 81,5 (71,7-106,9) and Me $47,4(39,1-56,3) \mathrm{mL} / \mathrm{min} / 1,73 \mathrm{~m}^{2}$ before and after operation, respectively, $\mathrm{P}=0,003$. In the group of patients who did not have renal dysfunction after CABG $(n=37)$, the change in GFR was not significant $(\mathrm{P}=0,252)$ and was the following: Me 91,2 (81,6-104,6) and Me 85,6 (70,2-99,6) mL/min/1,73 m² before and after the intervention, respectively.

We have analyzed GFR dynamics in some groups of the patients: patients who had CABG under $\mathrm{CP}$ conditions or on a beating heart without CP use; as well as in groups of patients with complications during the hospital period or in patients who did not have complications (cases of intraoperative MI, acute heart failure, which required use of inotropes, paroxysmal atrial fibrillation).

In the group of patients who had $\mathrm{CABG}$ under $\mathrm{CP}$ conditions, we observed a decrease in GFR with Me from 89, 1 (76,3$103,7)$ to $77,6(57,8-98,4) \mathrm{mL} / \mathrm{min} / 1,73 \mathrm{~m}^{2}, \mathrm{P}=0,036$. In the group of patients who had an operation without CP use, GFR also decreased from Me 96,4 (81,9-107,9) to Me 82,9 $(63,4-$ $91,8) \mathrm{mL} / \mathrm{min} / 1,73 \mathrm{~m}^{2}, \mathrm{P}=0,046$. Consequently, GFR significantly decreased in both groups, both when performing CABG under CP conditions and without CP use. However, significant differences in the level of GFR decrease due to CABG between the analyzed groups of patients have not been identified: in the group of patients who had an operation with the use of CP, GFR decrease was $29,4 \pm 3,1 \%$, and in the group of patients who had an operation without $\mathrm{CP}$ use, it was $19,5 \pm 4,6 \%, \mathrm{P}=0,392$.

In the group of patients with complications during hospital period after CABG $(n=23)$, a decrease in GFR in relation to the baseline was observed from Me $92(81,8-106,9)$ to Me 74,2 $(56,3-89,2) \mathrm{mL} / \mathrm{min} / 1,73 \mathrm{~m}^{2}, \mathrm{P}=0,000$. In the group of patients who did not have the above mentioned complications, no significant GFR dynamics was registered: Me 85,1 (76,2100,2) and Me 79,5 (61,1-102) $\mathrm{mL} / \mathrm{min} / 1,73 \mathrm{~m}^{2}$ before and after the intervention, respectively, $\mathrm{P}=0,797$.
Consequently, our study found that moderate transient decrease in GFR due to CABG in patients with CHD with pre-diabetes was observed in the whole sample of patients; in patients who have surgery performed under CP conditions, and on a beating heart without the use of $\mathrm{CP}$; a more pronounced decrease in GFR after the intervention was registered in the group of patients, who had complications during the hospital period.

To identify predictors of renal dysfunction due to $\mathrm{CABG}$, the patients with chronic CHD with early CMD were divided into 2 groups: patients who after CABG had GFR less than $60 \mathrm{~mL} / \mathrm{min} / 1,73 \mathrm{~m}^{2}(\mathrm{n}=11)$; and patients who after CABG had GFR higher than $60 \mathrm{~mL} / \mathrm{min} / 1,73 \mathrm{~m}^{2}(\mathrm{n}=37)$. In patients of the two groups the following parameters were analyzed: clinical and biochemical characteristics, EchoCG results, angiographic parameters, number of cardiovascular risk factors, blood glucose levels during OGTT, surgery indicators, average and peak values of glycaemia on day one after the intervention, need for short-acting insulin use for hyperglycemia correction on day one after the surgery and conducted therapy. The analysis included 68 characteristics. Indicators, for which there were differences $(\mathrm{P}<0,05)$ between these groups of patients, are presented in the Table.

It follows from the Table that a decrease in GFR after CABG less than $60 \mathrm{~mL} / \mathrm{min} / 1,73 \mathrm{~m}^{2}$ was associated with older age, lower baseline GFR and a prolonged period of CP.

Figures, presented in the Table, are included in a stepwise logistic regression analysis. A predictor of decrease of GFR less than $60 \mathrm{~mL} / \mathrm{min} / 1,73 \mathrm{~m}^{2}$ due to $\mathrm{CABG}$ in patients with chronic $\mathrm{CHD}$ with pre-diabetes was an indicator of $\mathrm{CP}$ duration ( $\beta=0,034, \chi^{2}=4,232, P=0,040$, the relative risk is $1,035,95 \%$ confidence interval is $1,002-1,069)$. Thus, the increase of the $\mathrm{CP}$ duration over Me 105 (86-136) minutes significantly increased a relative risk of the renal dysfunction process (GFR decrease after the intervention to less than $60 \mathrm{~mL} / \mathrm{min} / 1,73 \mathrm{~m}^{2}$ ) due to $\mathrm{CABG}$.

\section{Discussion}

Due to the steady increase in the number of patients with CMD or with renal dysfunction in a general population of the world population, the percentage of people with pre-diabetes,

\section{Indicators associated with a reduction in GFR to $<60 \mathrm{~mL} / \mathrm{min} / 1,73 \mathrm{~m}^{2}$ due to CABG in patients with chronic CHD with pre-diabetes}

\begin{tabular}{|c|c|c|c|}
\hline \multirow[t]{2}{*}{ Indicators } & \multicolumn{2}{|c|}{$\begin{array}{l}\mathrm{GFR}^{\star} \text { after } \mathrm{CABG}(\mathrm{mL} / \\
\left.\mathrm{min} / 1,73 \mathrm{~m}^{2}\right)\end{array}$} & \multirow[t]{2}{*}{$\mathrm{P}$} \\
\hline & $>60(n=37)$ & $<60(n=11)$ & \\
\hline Age (years) & $\begin{array}{l}59 \pm 7,2 \\
58(53-62)\end{array}$ & $\begin{array}{l}63 \pm 7,2 \\
66(59-69)\end{array}$ & 0,039 \\
\hline Baseline GFR ${ }^{\star}\left(\mathrm{mL} / \mathrm{min} / 1,73 \mathrm{~m}^{2}\right)$ & $\begin{array}{l}93 \pm 17,6 \\
91(82-105)\end{array}$ & $\begin{array}{l}82 \pm 21.2 \\
81,5(71.7-106.9)\end{array}$ & 0,010 \\
\hline $\mathrm{CP}^{\dagger}$ duration (min) & $\begin{array}{l}90 \pm 21 \\
85(74-100)\end{array}$ & $\begin{array}{l}108 \pm 25 \\
105(86-136)\end{array}$ & 0,030 \\
\hline
\end{tabular}

Annotation: the top row of the Table presents data of $\mathrm{M} \pm \mathrm{SD}$, the bottom row presents median and interquartile range.

Abbreviations: $\mathrm{GFR}^{\star}$ - glomerular filtration rate, $\mathrm{CP}^{\dagger}$ - cardiopulmonary bypass. 
as well as with $\mathrm{CKD}$, referred to surgical myocardial revascularization, are also increasing.

According to the analysis conducted in previous studies, the percentage of people with early CMD among patients with CHD is 37\% [10]. Similar results were obtained in our study: the percentage of patients with pre-diabetes among patients hospitalized for CABG was $32 \%$. According to I.Z. Kiladze et al. (2013) and J. Chalmers et al. (2012) [11, 12], the occurrence of III stage CKD among patients referred to CABG was $3,1 \%-5,4 \%$.

In our study, as well as in the works of Y.A. Morozov et al. (2008), A. N. Shonbin et al. (2013) and I.Z. Kiladze et al. (2013) $[2,4,11]$, there was a moderate decrease in GFR after surgical myocardial revascularization compared with baseline. The frequency of re-developed renal dysfunction due to $\mathrm{CABG}$ in patients with $\mathrm{CHD}$ with pre-diabetes was $21,7 \%$, which is also consistent with the results found in the literature on patients with stable angina: from $8 \%$ to $30 \%[3,13]$. Therefore, when analyzing the results of our restudy and data found in the literature, we did not receive confirmation of the fact that in patients with stable angina with pre-diabetes the incidence of renal dysfunction due to $C A B G$ is higher than in patients without CMD.

GFR decrease due to CABG was registered in interventions performed under $\mathrm{CP}$ conditions as well as in interventions on a beating heart without $\mathrm{CP}$ use. No significant differences in the severity of GFR decrease between groups of patients of $\mathrm{CABG}$ performed under $\mathrm{CP}$ conditions and on a beating heart without $\mathrm{CP}$ use were found, although the literature provides evidence that in interventions under $\mathrm{CP}$ conditions the incidence and severity of the following renal dysfunction is lower compared with interventions on the beating heart without $\mathrm{CP}$ use [11]. The discrepancy of our results and the data found in the literature is probably due to the fact that in our study the group of patients who had CABG on a beating heart without $\mathrm{CP}$ use was small $(\mathrm{n}=6)$.

We have also found that in patients who had complications during the hospital period following CABG, GFR decrease was more pronounced than in patients who did not have the complications.

\section{References}

1. Avaliani VM. Features of coronary artery bypass grafting in patients with systemic atherosclerosis. Arkhangelsk in 2007: 223

2. Shonbin AN, Zavolgin AS, Bistrov DO. The influence of myocardial revascularization method on frequency of acute renal damage during combined heart operations. Anesthesiology and reanimation 2013; 6: 89-93.

3. Leacche I, Rawn JD, Mihaljevic T, et al. Outcomes in patients with normal serum creatinine and with artificial renal support for acute renal failure developing after coronary artery bypass grafting. Am J Cardiol 2004; 93: 353-6.

4. Morozov JA, Charnaya MA, Gladyshev VG. Preoperative levels of glomerular filtration rate and the development of renal dysfunction after cardiac surgery. Cardiology and Cardiovascular Surgery 2008; 5: 62-4.

5. Filsoufi F, Rahmanian PB, Castillo JG, et al. Diabetes is not a risk factor for hospital mortality following contemporary artery bypass grafting. Interact CardioVasc Thorac Surg 2007; 75 (5): 1392-9.

6. Wijns W, Kolh Ph, Danchin N, et al. EAST Clinical Guidelines Committee: Guidelines on myocardial revascularization. The Task Force on Myocardial Revascularization of the European Society of Cardiology (ESC) and the Cardio-Thoracic Surgery (EAST). Eur Heart J 2010; 31; 2501-55.

7. National Kidney Foundation. K/DOQI Clinical practice guidelines for chronic kidney disease: evaluation, classification, and stratification. Am J Kidney Dis 2002; 39: 1: S1-S266.
The study shows that in patients with CHD with pre-diabetes, kidney dysfunction (GFR less than $60 \mathrm{~mL} / \mathrm{min} / 1,73 \mathrm{~m}^{2}$ ) after CABG was not associated with any of the indicators of glycemic control (fasting glucose and 2 hours after glucose load in GTT; peak and average blood glucose levels on day one after CABG). At the same time, we received confirmation of some of the facts cited by other authors, in particular, that older age, reduced baseline GFR and a prolonged CP period correlate with the renal dysfunction process after surgical myocardial revascularization $[4,11,14]$.

A prolonged $\mathrm{CP}$ period was a predictor of renal dysfunction process due to CABG in patients with CHD and pre-diabetes, thus the increase of CP duration over Me 105 (86-136) minutes significantly increased a relative risk of the renal dysfunction process after the intervention (GFR decrease after the intervention to less than $60 \mathrm{~mL} / \mathrm{min} / 1,73 \mathrm{~m}^{2}$ ). The obtain results are in close agreement with literature data, testifying that a prolonged $\mathrm{CP}$ period is one of the leading risk factors for renal dysfunction process after surgical myocardial revascularization $[4,11,14]$.

\section{Conclusion}

Thus, the following facts were the main result of our study. Almost every third patient, referred to CABG, has pre-diabetes. Patients with stable angina with pre-diabetes have a moderate transient GFR decrease after the intervention compared with baseline. In most patients, GFR reaches baseline by the time of discharge from the hospital. A more pronounced GFR decrease after the surgery is observed in the group of patients, who had complications during hospital period. The proportion of patients with renal dysfunction due to CABG (GFR decrease to less than $60 \mathrm{~mL} / \mathrm{min} / 1,73 \mathrm{~m}^{2}$ ) is $21,7 \%$. In view of our own results and literature data, the incidence of renal dysfunction due to CABG is not significantly different among patients with pre-diabetes and without CMD. The factor associated with the process of postoperative renal dysfunction in patients with chronic CHD with pre-diabetes is a prolonged $\mathrm{CP}$ period. The increase in the $\mathrm{CP}$ duration to over Me 105 (86-136) minutes significantly increases the risk of postoperative renal dysfunction.

8. Cardiovascular risk and chronic kidney disease: cardio-nephroprotect strategy. Recommendation CSC, NONR, RAE RMOAG, Noah, RNMOT. Moscow 2013; 55.

9. WHO Consultation. Definition, diagnosis and classification of diabetes mellitus and its complications. Geneva: World Health Organisation 1999; Report no.99.2.

10. Poddubnaya EA, Mamedov MN. Fundamentals of early diagnosis of HMD in general therapeutic practice from the standpoint of evidence-based medicine. Cardiovascular therapy and prevention in 2012; 5: 83-9.

11. Kiladze IS, Morozov AV, Uryuzhnikov VV, Goncharova AV. Features of renal dysfunction in patients undergoing myocardial revascularization. Anesthesiology and coronary 2013; 4: 55-9.

12. Chalmers $\mathrm{J}$, Mediratta $\mathrm{N}, \mathrm{McShane} \mathrm{J}$, et al. The Long-term effects of developing renal failure post-coronary artery bypass surgery, in patients with normal preoperative renal function. Eur J Cardiothorac Surg 2012; 15: 25-9.

13. Sigitova ON, Bogdanova AR. Predicting the risk of acute kidney injury in patients with coronary artery disease. J of Modern Clinical Medicine 2013; 5: 18-23.

14. Kandaurov Al, Chwokov AV. Renal function after fusion surgery in patients with multifocal atherosclerosis mainly affecting the coronary and carotid arteries. Cardiology and Cardiovascular Surgery 2014; 2: 74-6. 